\title{
The Presentation of Trauma in Museums: The Museum of the Occupation of Latvia and the National Museum of Qatar as Case Studies
}

\author{
Mariam I. Al-Hammadi \\ Department of Humanities, Qatar University, Doha, Qatar \\ Email:m.alhamadi@qu.edu.qa
}

How to cite this paper: Al-Hammadi, M. I. (2021). The Presentation of Trauma in Museums: The Museum of the Occupation of Latvia and the National Museum of Qatar as Case Studies. Open Journal of Political Science, 11, 569-593.

https://doi.org/10.4236/ojps.2021.114037

Received: July 5, 2021

Accepted: August 27, 2021

Published: August 30, 2021

Copyright $\odot 2021$ by author(s) and Scientific Research Publishing Inc. This work is licensed under the Creative Commons Attribution International License (CC BY 4.0).

http://creativecommons.org/licenses/by/4.0/

(c) (i) Open Access

\begin{abstract}
This paper attempts to explore the theme of Trauma and its representation in the Contemporary World; in particular, the logic and argumentation of having museums presenting the sorrow side to people the "trauma", is unfolded with the rationale of comparison of two cases the Museum of the Occupation of Latvia (MOL) and the National Museum of Qatar mainly dealing with the emerging message of new Qatar National Trauma Museum. The current political incident came to proof the necessity to remind people about historical events and their link to the recent incidents. The museums as a contact zone provide public lessons from the past that is a creative and stored memory. The analysis of the concept of trauma touches on questions such as why Latvia and Qatar need such Trauma Museums, how this museum builds the traumatic narrative and discusses the potential effect on the local people. The aims of this comparison focus on the value of safeguarding of the nation through remembrance and that although museums presenting trauma may seek to educate and evoke pride in visitors for fellow residents, the main task is to avert the recurrence of what led to the trauma, which could be blockade, war or occupation that cut aggressors loose. The methodological tool of the theme follows properly designed exhibitions and making use of new technologies, by contextualizing museum exhibits and practices as made by both Latvia and Qatar on the basis of national identity triggered from the past atrocities, on a holistic approach. This includes, especially, the social effects and movement associated with the blockade in Qatar and the War with Nazi-Russian occupation for Latvia, viewed as the development of presentation of traumatic memories that addresses and understands the interrelationships between politics and culture, political culture and cultural politics.
\end{abstract}

\section{Keywords}

Atrocity, Cultural, Social, Blockade, Memory, History, Holocaust 


\section{Introduction}

Over the centuries, people have found themselves locked in a multitude of conflicts that, although involving a variety of nations, can be characterized as rather regional.

Following the tumultuous events of the twentieth century, many communities were left devastated and in a state of national confusion. In the resulting aftermath of unresolved trauma, the memory museum was destined, henceforth, to guide wounded communities to a place of collective memory to achieve a clearer sense of national self (Black, 2011).

The seventeenth and nineteenth centuries saw multiple conflicts between Arabian Gulf countries, but that was documented only in some references and not talked about publicly and frankly. During those conflicts, all manners of violence and killing were committed between Arabian tribes, which were driven by greedy desires. Such as desire to control, occupy and break sovereign. Qatar an Arabian Gulf country endured the attack of its neighbors, whether political disagreement or military conflicts and confrontations. Although the current decade did not witness any military conflicts, however, it did witness a political confrontation and dispute.

The twentieth century also saw two global conflicts break out, the latter being the Second World War. Spanning a total of six years, it led to all manner of atrocities being committed, including at a time of occupation. Latvia, a Baltic state in the north of Europe, endured the Nazi-Soviet occupation in the 1940s and the decades after when the USSR survived and thrived as a geopolitical player pending its eventual dissolution (Davoliute \& Balkelis, 2012). Deportations, outright annihilation, and acculturation occurred during these decades. It is vitally important that people not forget their historical mistakes that translated into regional or international conflicts that left many states harmed or occupied, with local residents subjected to brutal regimes ${ }^{1}$.

The preservation of the memory of the past as heritage (tangible and intangible) and traditions has a place to tell a story, the museums. Different types of $\mathrm{Mu}$ seums present thematics related to history, environment, archaeology, pre- and post-industrial era (Silverman, 2015).

This is what museums are for and many are not aliened to presenting the wartime and occupation-period trauma in its entirety, which may perform a variety of important functions and shape people's attitude towards specific nations only for it to persist in the time to come. Here the logic and argumentation of having museums presenting the sorrow side to people the "trauma", is unfolded with the rationale of comparison of two cases the Museum of the Occupation of Latvia (MOL) and the National Museum of Qatar. The selection of these museums was at the author's choice being Qatarian and after her visit to MOL.

The National Museum of Qatar $(\mathrm{NMoQ})$ initiated the presentation of trauma

${ }^{1}$ Romuald. J., \& Misiunas R.J. (2020) “Baltic states". Britannica. Available online:

https://www.britannica.com/place/Baltic-states/Soviet-occupation. (Accessed on 25 March 2020) 
after decades of the state of Qatar being silent and tended to hide such historical conflicts, and that presentation was organized into two exhibitions, which contain rich information (Al-Hammadi et al., 2020). Unlike Qatar, in Latvia, a whole museum is dedicated to present the hardship time that the Latvian people experienced. The MOL is one of such impactful, trauma-presenting establishments. Those two museums will be the focus of this paper as a case study of the presentation of trauma at museums. Considering the current geopolitical shifts in the Gulf region on the one hand, and the rise of far-right parties on the other hand, the article about the Museum of the Occupation of Latvia and the National Museum of Qatar addresses a highly relevant topic. However, while both museums certainly deserve academic attention, and the selection of case studies was intentional for presenting the trauma case, which shares human pain and memories beyond the conventional heritage history and it is this rationale which makes interrelations between the two museums of interest. The objective of the paper is the investigation of the social importance of trauma in the Occupation of Latvia and The National Museum of Qatar, following a holistic approach.

\section{A Brief Overview}

The role of museums and art institutions play in international relations today and specifically in the development of what Joseph Nye called "soft power" should be carefully considered (Nye, 2004). At any rate it is a risky however phenomenon that the state could possibly exploit museums' narratives for the benefit of certain political projects. The links between the political power of the state and museums has been discussed. Politics is an art, and art today, has a great deal to do with politics (Luke, 2002: Chapters 1 and 5).

Museum and art institutions have long been at the forefront of representing cultural values and morals, being utilized as locations of instruction for centuries. It is no wonder that in a world that is increasingly connected, these same institutions come to play their roles on international levels and have increasingly been used in International Relations.

Apart of the loan policy of cultural artefacts creation the development of a favorable image on an international level involves politics and money.

The key starting-point for this consideration of the exercise of direct political power in the museums context lies in the symbolic representational role of national museums.

The relationship between Museum and Society must refer to a wide range of social science, humanities and practitioner research including, society, practice, funding and management, conservation, identity and difference, social inclusion, audience research, access provision and practice, education, politics and display, heritage studies, history of museums/collections, government policy and museums, reviews of temporary exhibitions to book reviews.

Some examples of museology and trauma indicate the significant impact it has to the society in preserving the memory. 
The development of the Remembering the Killing Fields exhibit and the collaborative process involved in producing a successful and meaningful exhibit for the Cambodian community and the general public, involving trauma, memory and collaborative efforts from society has been reported (Salazar, 2015).

Although the term "trauma" is initially used in the field of medicine in regarding the examination of the body, which means opening the surface-skin and going deep into the interior of the body. The etymology of the terms takes us back to the Greek history in the $17^{\text {th }}$ century, where the concept of trauma is associated with the meaning of both body and psychic wounding or piercing. Within the contemporary context, analyzing the concept of trauma, Pollock (2013) suggests five defining features of trauma; perpetual presence, permanent absence, irrepresentability, belatedness and transmissibility (Pollock, 2013).

In another case, the exploration of the theme of trauma and its representation in Contemporary Art, in particular, analyzes the concept of trauma with its origin as a term in human history. Kulasekara (2016) brings a comprehensive understanding of the human body and psyche as a subject and content of the works produced in Contemporary Visual Arts. On this basis, this work forms an extensive discussion of the representation of physical and psychological traumas in works of art.

After all what is the pedagogical value of museums and their relationship to communities of trauma? Yet a problem arose when one begins to consider the question: what constitutes a community of trauma? The $20^{\text {th }}$ century has encompassed an endless cycle of violence (Brown, 2004).

A comparison of how trauma has been represented in Jewish and Holocaust museums since the Second World War and the National Museum of the American Indian (NMAI) in Washington, 2004, highlighting the possibilities and limits of museums when representing the history of genocides in countries where victims and their descendants continue to live alongside perpetrators and their heirs. The power and the desire to represent oneself on the museal platform have been examined, followed by a discussion of concepts associated with trauma [self-healing, zakhor (remembrance), tikkun olam (repairing the world), temporal considerations, survival, and resilience] in the context of museological representations (Greenberg, 2007).

According to the decree of May 1994, by the first president of the Republic State of Armenia Levon Ter-Petrosyan "On Establishment of State Commission for Organizing Events dedicated to the $80^{\text {th }}$ Anniversary of the Armenian Genocide", the Armenian Genocide Museum was set up by the number 122 decision of the government of Armenia on March 7, 1995 to remember the Turkish produced trauma. In September 29, 1995, on the 80 anniversary of the Armenian genocide the main exhibition of the Museum-Institute was opened (Artistic development was led by architect Haykaz Qochar). The building of the museum was state-financed, as well as was provided by the funds of Armenian General Benevolent Union and "Hayastan" All-Armenian Fund. The Museum is in- 
cluded in the RA National Academy of Sciences, and has a status of research institution (see: http://www.genocide-museum.am/eng/MemoryAlley.php).

The word genocide was created by combining the Greek word "geno," for race or tribe and the latin word "cide," from Greek "kteino", for killing.

The recurring idea that memory museums are a social construct to communicate memory to help current generations negotiate a difficult past, has been discussed in terms of "memory museum" (Silk, 2016).

Moreover, in understanding how the House of Terror uses their exhibition spaces to produce a biased historical narrative for political ends in a post-dictatorial country is another epistemologic issue. The clear curatorial analysis helps frame and justify the arguments around the problematic nature of historical inaccuracy in memory museums (Apor, 2014).

Bassanelli and Postiglione (2003) efficiently communicated the abstract notion of memory as a tool for negotiating cultural identity following traumatic national events, and their strong definition of abstract ideas employed by museology strengthened the conceptualisation of the case examples used.

The ethnographic methodology of how high school students interacted and responded to a museum is to strengthen e.g. the Jewish Berlin Museum case study through highlighting its relationship to its local audiences (Bishop Kendzia, 2010).

It has been shown by Bishop Kendzia's (2014) idea that museum rituals create collective identity as a national function but the attitudes displayed are not authentic as they contradict typical German prejudices against minorities.

Brown's (2004) article is useful in its analysis of how museums guide nations, who have experienced crisis, through their cultural collections. From his theories about trauma's relation to the body, the symbolic use of the artefact, the ritual of memory and the issue of reconstructed histories within museum education were evidently expressed. His argument was pivotal in articulating the arguments concerning the social and ethical relationship between museum, memory and trauma.

In the following section the rationale of having Museums which preserve trauma is discussed and the context of the two case studies is presented, following the discussion of each case study and conclusion.

\section{Why Museums Present Trauma. Why They Are Right to Do So?}

Dian Lees, the current director-general of the Imperial War Museum based in the UK, opined that conflict, trauma, uneasy circumstances and war, would always be fascinating to a specific segment of the audience and that the museum sought to widen that audience, which, however, may be a dangerous formulation. A report centered on whether trauma, conflict and war belong in museums warned about the threat of the unwitting romanticizing of the past via museum displays. Striking a careful balance is about presenting the less enjoyable sides of 
history as well even if doing so ends up disturbing the nostalgic and romantic images that some people love to foster. Whether the IWM's director was inaccurate while describing the intention of the museum or whether they truly seek to multiply the number of people, to whom its content is "fascinating" or attractive, may be debatable. If fascination was the accurate verbalization of the purpose of the British museum, the administration is wrong to create such an atmosphere that gets people developing a romantic perception of the war, for it may arouse the dormant aggressive side of visitors who may have the power, influence, and monetary resources needed to set the war machine in motion. Still, many museums are oriented towards shaping a clear pacifist way of thinking, which can make a case for why such establishments should present the trauma. As seen in the case of the National Museum of the History of Ukraine in the Second World War, the goal of such establishments is for people to understand the tragedies of wars and uncover the truth about the heroism and sacrifice of local people. What the museum also does is demonstrate ways to prevent war tragedies from recurrence.

Apparently, museums cultivate pride in ancestors, which should evoke the motherland-loving sentiment in those who have yet to go patriotic.

A measure of the effect of museums' discourse on the formation of a national patriotic spirit is supported by an actual audience study, which gauges the aim and has been made elsewhere for the two cases (Al-Hammadi et al., 2020).

The sacrifice themes should make people appreciate the feat of ancestors and refrain from hostilities out of respect. Understanding the trauma and war, in turn, may foster unreceptiveness thereto as the romantic aura likely surrounding it will be gone, which should activate realistic thinking, that is, people will think straight, without being guided by romantic illusions, when tempted by the idea of initiating a conflict of some kind (Luke, 2002). Now it remains to be clarified whether the National Museum of Qatar and Latvian Museum of Occupation seek to dampen any potential proclivity for aggression, without stoking it up.

\section{The Context of the Two Museums}

Though both Museums compared here serve the same purpose the legal entities it is worth quoting some quantitative and policy issues to help in correlating these two case studies. The MOL is the Museum of the Occupation of Latvia's association as legal owner and manager and the association is a registered on the registry of Latvian state associations and foundations, and operates in accordance with the laws of the Republic of Latvia and the statute of the MOL. Although it receives annually around 100,000 visitors, recently it lost 3/4 of its visitors due to economic difficulties ${ }^{2}$.

"Latvian Museum of Occupations under Serious Threat” (2015). Platform of European Memory and Conscience. Available online:

https://www.memoryandconscience.eu/2015/11/30/latvian-museum-of-occupations-under-seriousthreat/. (Accessed on 17 April 2020) 
MOL is a historic educational institution located in Riga, Latvia and the stated mission is: 1) to show what happened in Latvia, its land and people under two occupying totalitarian regimes from 1940 to 1991 ; 2) to remind the world of the crimes committed by foreign powers against the state and people of Latvia; and 3) to remember the victims of the occupation: those who perished, were persecuted, forcefully deported or fled the terror of the occupation regimes.

It was established in 1993, it contains more than 60,000 registered items, it includes in collection an audiovisual archive containing more than 2300 video testimonials of deportees, refugees, and others affected by the occupations of Latvia, and the audiovisual department has also made 10 documentary films ${ }^{3}$. MOL's motto is: remember, commemorate and remind.

To the contrary the NMoQ is staright a state owned and governed and the resources are state funding. The museum encompasses a total area of almost 40,000 $\mathrm{m}^{2}$ and offers $8000 \mathrm{~m}^{2}$ of space for permanent exhibitions and $2000 \mathrm{~m}^{2}$ for temporary exhibitions, overlooking the Corniche promenade at Doha the capital city of Qatar. In addition to that it includes also a $112,000 \mathrm{~m}^{2}$ park with an artificial lagoon, laboratories a research center, an auditorium with 220 seats, a conference room with 70 seats, storage facilities and conservation of the collections and a museum shop, two restaurants and a cafeteria (URL:

https://en.wikiarquitectura.com/building/national-museum-qatar/, accessed on 17 March 2021). The museum includes 220-seat auditorium, where the story of Qatar is narrated across 11 galleries and across $1.5 \mathrm{~km}$ of walkways ${ }^{4}$. The museum offers a rich exploration of Qatar through its three main sections. These are "Beginnings", "Life in Qatar" and "The Modern History of Qatar"5. NMoQ aims to give voice to the unique story of the state and its people; right from earliest times to the present day and onwards towards the future.

In order to fully engage the public, the NMoQ creates multi-layered experience through its galleries, which are full of colors, movement, and sound. Such experience is meant to integrate public's emotions and senses as well as their intellects ${ }^{6}$.

Its outreach programs are delivered either online or at the museum's building. Such as, discovery programs, school tours, adults and family tours, kids in museum manifesto, e-learning, teacher training, hosting an event at the Museum. Those, programs target students, scholars, families and individuals from different nationalities and ages. The museum has also developed strong relationships with local schools through a number of inclusive programmes, including the

\footnotetext{
${ }^{3}$ Museum of Occupation of Latvia. 2020. Available online: http://okupacijasmuzejs.lv/en/about-us/the-museum-collection. (Accessed on 17 April 2020)

${ }^{4}$ National Museum of Qatar. Learn. Available online: https://nmoq.org.qa/contact-education. (Accessed on 7 December 2020)

${ }^{5}$ National museum of Qatar, Available online:

https://www.qm.org.qa/en/project/national-museum-qatar. (Accessed on 25 May 2020)

${ }^{6}$ National Museum of Qatar welcomes over 132,000 visitors in first month. The Peninsula. Available online:

https://www.thepeninsulaqatar.com/article/08/05/2019/National-Museum-of-Qatar-welcomes-over -132,000-visitors-in-first-month, 8 May 2019. (Accessed on 17 March 2021)
} 
Teacher's Council. NMoQ has welcomed over 132,000 visitors in the first month of its opening, firmly confirming its important role in the country's cultural infrastructure. The museum attracted thousands of residents and tourists with its use of audio-visual presentations ${ }^{7}$.

The devices that display traumas in the NMoQ combined visual, verbal, sounds and barbule evidence that have been collected from historical references. And current evidence has been collected from human right organization in Qatar. The historical traumatic stories displayed in cabinets, showcase for the first time correspondent letters, documents of battels and attacked that Qatar encountered with its neighbors. The exhibition of modern Qatar designed as informative exhibition in narrating the trauma. Transparent hanging or standup panels (Figure 1), which provides full scene for the audiences for all directions. Such sensory visual and verbal presentations as seen in Figure 1 are privileged to touch the visitors.

The NMoQ mission and vision is to develop, promote and sustain the cultural sector at the highest standards. The mottos of the museum are: Taking Museums Beyond Four Walls, Nurturing Emerging Talent and Creating a Platform for the

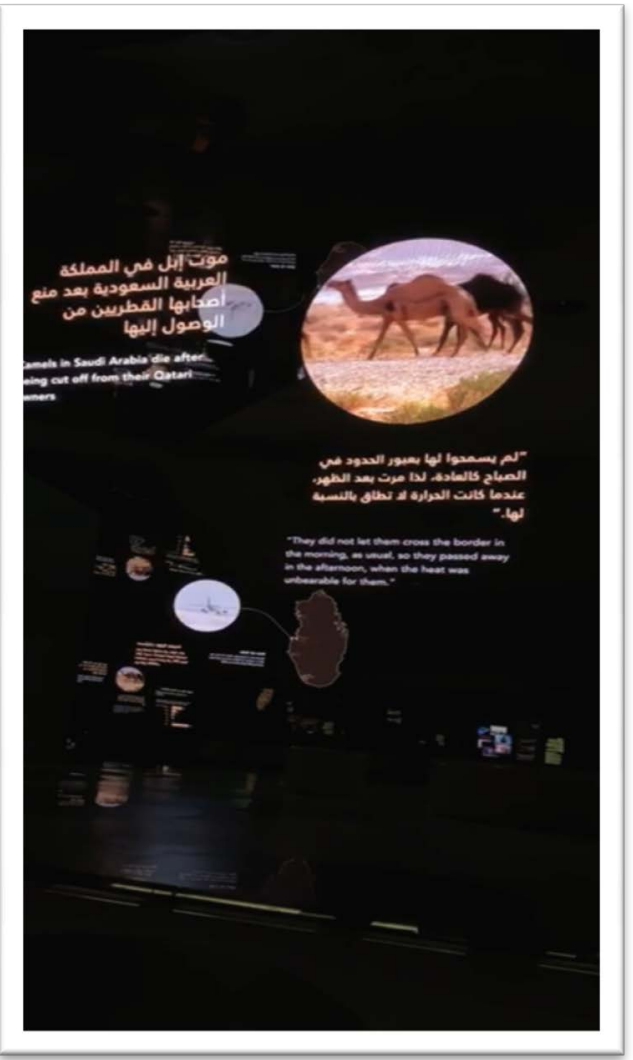

Figure 1. A digital screen displays and narrates what camel could not be endured in the middle of hot desert (Photo taken by the author NMoQ, 19 November 2019).

${ }^{7}$ National Museum of Qatar welcomes over 132,000 visitors in first month. The Peninsula. Available online:

https://www.thepeninsulaqatar.com/article/08/05/2019/National-Museum-of-Qatar-welcomes-over -132,000-visitors-in-first-month, 8 May 2019. (Accessed on 17 March 2021) 
Voice of Qatar. The trauma exhibitions in NMoQ are dedicated to the history of political conflict about the political history of the state, which the state kept disclosed for decades as a respect to its neighbors.

In spite the differences in ownership and funding policies the essential point I think is the targeted aims, which both serve for the society and the World.

\section{MOL and NMoQ: Recurrence Precaution through Memory}

There is a now-popular phrase often aired by politicians, whether populist or otherwise, activists, and others, which suggest, "Never Again." An article from the Times of Israel shows the roots thereof. Some have traced it to the poem called "Masada" meaning "Never Shall Masada Fall Again" written by Isaac Lambdan, a Hebrew poet. Still, its modern-day use has more to do with postwar Israel that it does with the poem predating it by several decades. First employed in secular kibbutzim in the late 1940s, it was later picked up in a Swedish documentary on the Holocaust in $1961^{8}$. The application context of the phrase goes to show that it is supposed to remind people of how bad it is to be waging conflicts and repressing people in the cruelest way imaginable. This is why museums presenting traumas are needed. Just as the phrase mentioned shows the unacceptability of traumatic events, so too does the museum that verbalizing the message via a set of carefully preselected visual artifacts.

Truly, if there is one chief reason museums, such as that in Latvia, see fit to get the traumatic experience of people presented, it is for them not to make the same bad call that would lead to people being traumatized. It is smart of museums to do so, since it is like people to forget whatever bad happens to them, which is a prerequisite for historical relapse'. As a prominent German philosopher Friedrich Hegel said once, "What experience and history teach is this-that people and governments never have learned from history or acted on principles" (Archer, 2010). Stated otherwise, people tend not to learn historical lessons any more than governments do which causes them to commit the same fatal mistake in as short a period as twenty-one years, as was the case with the WW2 that erupted but several decades after the first global conflict subsided. Therefore, people do need there to be the ever-alive narrative of wartime atrocities. Such atrocities nations may not always source from eyewitnesses and victims. Even if an occupation survivor, a person may not keep the traumatic experience in mind. While people to have had a trauma inflicted on them, be it physical or emotional, in the course of a state-wide calamity often remember it, many others may not. It may be that the collective memory of people fades as new generations come, with

\footnotetext{
${ }^{8}$ Burack, E. (2018). How "Never Again” Evolved from Holocaust Commemoration Slogan to Universal Call. The Times of Israel. https://www.timesofisrael.com/how-never-again-evolved-from-holocaust-commemoration-sloganto-universal-call/. (Accessed on 17 April 2020)

${ }^{9}$ Matthew, M. (2016). “The Far Right in Latvia: Should We Be Worried?”. Sicherheits Politik-Blog. Available online:

https://www.sicherheitspolitik-blog.de/2016/04/01/the-far-right-in-latvia-should-we-be-worried/\#f n-7811-2. (Accessed on 17 April 2020)
} 
traumatic memories passed less often on to young individuals, while older generations pass away never to share their experience with others, still less document it, so do their untold memories. Moreover, surviving occupation and war witnesses may have no way of making their experience known to younger residents for a number of reasons $s^{10}$. One of those reasons, for instances, can be related to the nature of the relationships that link GCC's societies. Those nations have now peaceful and good relationships and reviving the memories of hardship times would not benefit them. Qatar, as an example, its government and people alike have never talked about the historical conflicts and tension that used to be between the state and its neighbors. This was due to the strong relationships that link Qatari families with families in GCC's countries, which created a good and stable social fabric between those states for decades.

Also, some were too young at the time of the war and hostile occupation to remember and contribute to the respective memory being kept alive in the country, yet not all the reasons are as prosaic (Wolfgang, 2013). Since Europe has not seen any conflicts unfolding since the WW2 coming to an end, many occupation witnesses may be hard-pressed to remember it, which could be down to state-dependent memory. As explained in the book on forensic psychology, the memory implies that people will not be able to easily recollect things experienced in psychological or emotional states, fear included, unless in the same state. Moreover, the book talked about avoidance behavior when people shun reliving the trauma. As appears, when traumatic, memories may be frozen in their original form and left unmodified for further experience. Subsequently, reliving such negative experiences can prove traumatizing, since their retrieval is akin to reexperiencing them. It is said to be different from repressed memory (Bartol \& Bartol, 2014), which is understood to be the inability to recollect information about a traumatic event that, although stored in the long-term memory, is not accessible as access thereto is blocked by psychological defense mechanisms. This is to suggest that the lack of conflicts does not provide the same preconditions for memory recollection; nor can the traumatic experience be recalled due to the avoidant behavior and repressed memory that can be protective memory mechanisms. This leads some occupation survivors to fight shy of sharing their negative experience with younger generations, which could plant an understanding of how important it is to avoid repeating the same mistake, which is why the main thing that trauma-presenting museums can be doing is telling younger residents what occupation survivors do not want to over the mentioned reasons. Furthermore, from want of ongoing conflicts, it may be hard for younger people to engage in shoe-shifting or demonstrate empathetic intelligence for a reason (Sherman, 2016). They who experienced the same tragedy can

${ }^{10}$ Jacqueline, R. (2011). Clinical Consult for Psychiatric Mental Health Care, New York: Spring. Robins-Early, Nick. "Far-Right Politicians Are Using Coronavirus To Push Anti-Immigration Xenophobia.” Huff Post, February 28, 2020. Available online:

https://www.huffpost.com/entry/far-right-coronaviruseurope_n_5e597431c5b601022110798b. (Accessed on 17 April 2020) 
understand others better than those who did not. This understanding and remembering are very essential as the means to discourage conflict/violence reoccurrence.

In theory, if present centuries ago, a presentation like that encouraged at previous Qatar national museum, that could have provided people a better understanding of political relationships between Qatar and its neighboring countries. Similarly, if present centuries ago, a museum like that in Latvia could have saved the lives of many by reasoning people out of embarking on military conflicts. If only conflicts were born out of the trivial non-understanding of the gruesome side of confrontations. When people set foot on the warpath, they do understand the bloody nature of such, so do they the fact that brutality brings economic dividends, which is what drives them, yet there should be no ruling out the containment utility of trauma-presenting museums that can interact with visitors at the emotional level using the power of very graphic presentation. By being physically present, such establishments will not achieve the intended goal, however, unless visited by most residents at some point so that they may get a lasting impression, such that they will not do so much as consider hostilities in any format. Thus, there is a chance that people's historical amnesia is minimized via the attitude adjustment potential of trauma-presenting museums. Conflict-presenting museums can stimulate the understanding of the atrociousness of tribal "in the case of Qatar" or military conflicts "in case of Latvia" and authoritarian regimes through a strong, convincing visual panorama of the events that can also do much to build a strong national identity.

\section{Critical Discussion on the two Cases}

\subsection{Forging a Strong National Identity of MOL: Useful Values}

As follows from the origin of the items, whether tangible or otherwise, which the museum laid available, people have shared their stories, apart from donating artifacts, which they did in an effort to retain the memory of the occupation period. Consequently, museum employees have recorded an aggregate of 2300 video testimonies, which is regarded as one of Europe's biggest collections dedicated to the occupation topics. The donated objects and testimonies were claimed to add personal experience to history via the life story of each individual. Rather than talk about suffering exclusively, the memories talk about resistance, selflessness, and endurance ${ }^{11}$. These could be the values that the government wants absorbed by Latvians. If they become a part of the national identity, they may go a long way towards strengthening people's unity and make residents impervious to foreign influence and pressure, which can be emanated from a revanchist neighbor state. In fact, Latvia now needs people resistant to pernicious foreign influences. It also needs people remembering the atrocities more than ever now that dan-

11"Museum of Occupation of Latvia, Riga.” Dark Tourism. n.d. Available online: http://www.dark-tourism.com/index.php/republic-of-ireland/15-countries/individual-chapters/935 -riga-occupation-museum\#p. (Accessed on 17 April 2020) 
gerous geopolitical and domestic developments are brewing that can put it on the collision course with those who used to mistreat its residents in the decades of the occupation.

\subsection{Why Latvia Needs the Museum More than Ever-Russian Aggression Probability \& Nazism Resurgence}

While Latvians may be given to understand that conflicts and authoritarian regimes are an absolute evil via museum-based expositions, a political regime hundreds of miles to the east seems to be fostering a different idea all the while eying the recapture of its former Baltic domain. A report in the Guardian suggested that Lithuania lest the Russian propaganda, which led to history being falsified and the Baltic state being denied the right to exist, be a prelude to an eventual invasion $^{12}$. The same, however, can be said of Latvia that, alongside Estonia and Lithuania, have spent decades confronting disinformation campaigns, and the museum is a way not only to retain history but also show who was who in it. So that there may be no illusions regarding Russia whose propagandistic overtures may finally be understood as a steppingstone for restoring its brutal regime in the Baltic state by those residents who have not managed to grasp the role of the eastern neighbor in Latvia's woes ${ }^{13}$. Interestingly, the Kremlin must understand the danger of there being a museum that discredits the Soviet Union whose collapse is bewailed by the Russian leadership and whose domains it may seek to restore; otherwise, the museum would not be sabotaged the way it is ${ }^{14}$. As per one of the reports, the administration of the City of Riga under Mayor Nils Ušakovs is believed to be intentionally protracting what is the untenable situation around the museum. The earlier approved expansion plans have been frozen. After the museum having to survive in its modern quarters for a few years, its audience is $75 \%$ short of its 100,000 yearly visitors, which means that the facility runs the risk of slamming its doors shut due to economic considerations ${ }^{15}$.

Latvia stands a far better chance of averting the revanche of the toxic ideology along with the legal and social transformations that may follow the victory of politicians with the far-right ideological platform. If residents should visit the museum, they should absorb the undisguised truth about the brutal German re${ }^{12}$ Graham-Harrison, E, and Boffey. 2017. "Lithuania Fears Russian Propaganda Is Prelude to Eventual Invasion". The Guardian.

(https://www.theguardian.com/world/2017/apr/03/lithuania-fears-russian-propaganda-is-prelude-t o-eventual-invasion). (Accessed on 17 April 2020)

${ }^{13}$ Thompson, T. (2019). Countering Russian Disinformation the Baltic Nations' Way. The Conversation, January 9. Available online:

https://theconversation.com/countering-russian-disinformation-the-baltic-nations-way-109366.

(Accessed on 17 April 2020)

14“Mayor Slams Sanctions, Stresses Moscow Ties." LSM.LV. August 12, 2014. Available online: https://eng.lsm.lv/article/politics/politics/mayor-slams-sanctions-stresses-moscow-ties.a94391/.

(Accessed on 17 April 2020)

15“Latvian Museum of Occupations under Serious Threat". (2015). Platform of European Memory and Conscience. Available online:

https://www.memoryandconscience.eu/2015/11/30/latvian-museum-of-occupations-under-seriousthreat/. (Accessed on 17 April 2020). 
gime, which can keep residents immune to the venomous doctrine or change the mindset of Latvians leaning towards the ideology over its illusionary perception, that is, the ones espousing it. The advocacy of far-rightism is unsurprising, since politicians have it in them to play on people's disillusionment, including that with the cosmopolitan ideology of border-free Europe. How political forces come to power does not matter that much; what does is that the mentioned adverse outcomes of the far-right ideology presence can be avoided. To ensure this outcome, the museum has built the traumatic narrative in a specific way ${ }^{16}$.

\subsection{How the Latvian Museum Builds the Traumatic Narrative}

When it comes to how it is that the museum builds the traumatic narrative, it is described as located in a single large room split into sections by well-placed interior partitions that put historic photographs, illustrations, maps, documents, and artifacts on display (Figure 2). The museum ensures the availability of the contents to the multinational audience by placing texts in English, German, Russia, and Latvian at their disposal, yet this somewhat curtails the depth of explanation attached to the exhibits.

The article showed that the museum personalized the exhibits in the sense that a long exterior wall was reserved for personal items possessed by people who had different occupation experiences as some endured, fought with partisans, perished in camps, or faced deportation (Gundega \& Koknevièa, 2008) (Figure 3).

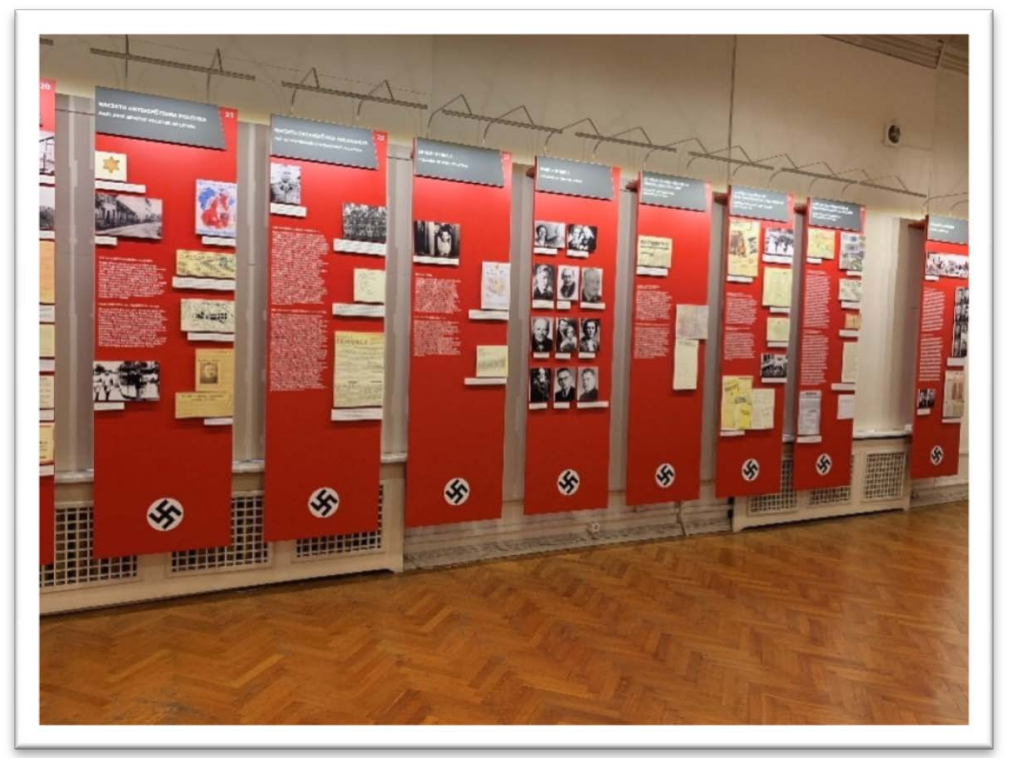

Figure 2. The presentation of the museum, which focused very much in adding various testimonies, such as people memories, individual photos, and public news (Taken by the author on October 2019).

\footnotetext{
${ }^{16}$ Zabala, Santiago, 2019. Spain's Far Right Hates Not Only Immigrants, but also Women. Aljazeera, January 20, 2019. Available online:

https://www.aljazeera.com/indepth/opinion/spain-hates-immigrants-women-190120105425265.ht ml. (Accessed on 17 April 2020)
} 
More to the personalization of the exhibition, one of the gulag accounts provided in 1994 by Martins Bisters details one of the aspects of the despicable treatment of people by the Soviets, which it referred to as "Parasha" defined as mobile and ever-disgustingly smelling commode utilized in Russian concentration camps and jails (Figure 4).

The deportation survivor suggested that it had been put in barracks, cells, Stolypin's wagons, and cattle wagons likely indicating the inhumane transportation conditions and vehicles used to this end. There being unsanitary conditions and

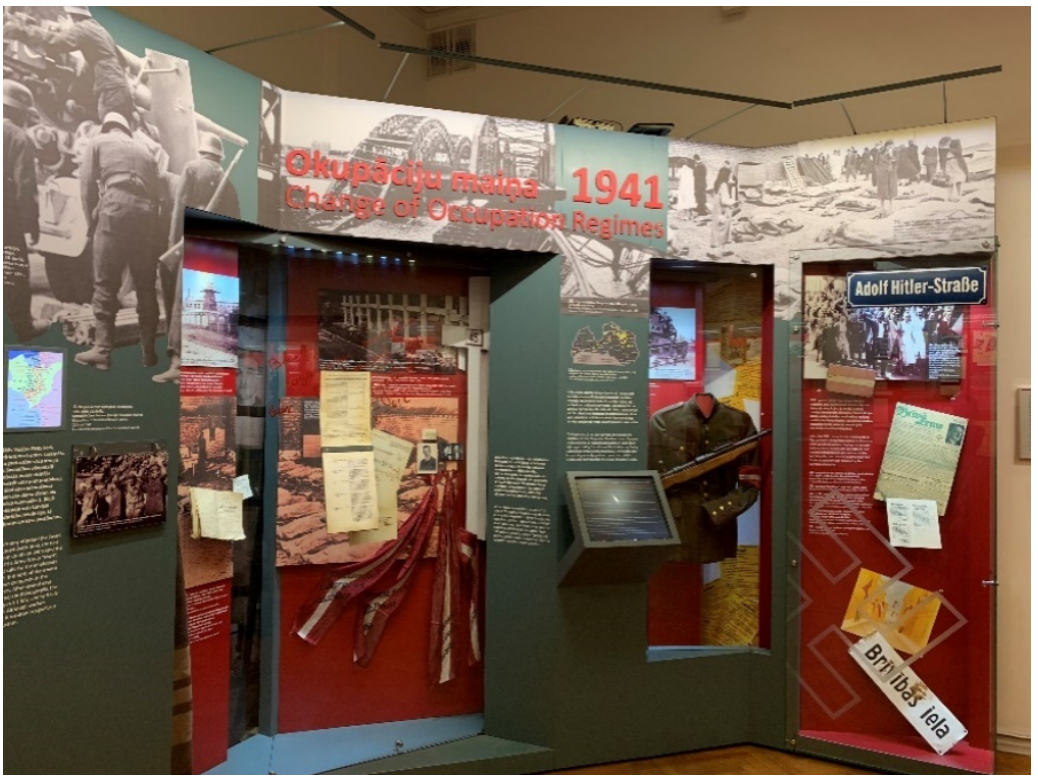

Figure 3. Change of Occupation Regimes (Photo by the author on October 2019).

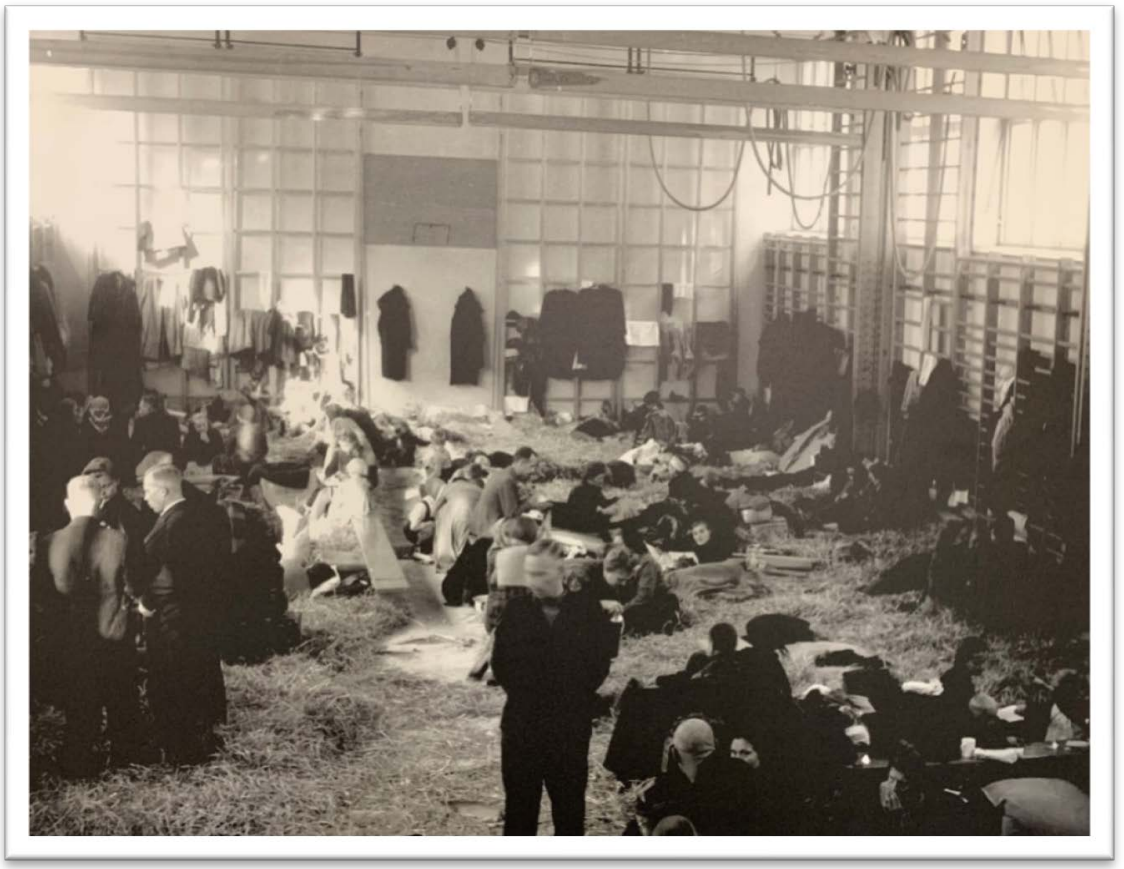

Figure 4. The Parasha Prison (Taken by the author on October 2019). 
unfamiliar food, Latvians suffered diarrhea. That may be unsurprising, seeing that excrements were pouring or falling splashing the clothes and behinds of the ones sitting on the improvised toilet. Never in 15 years of incarceration did the man get to use toilet paper. The prisoners reportedly stank from filthiness that defied belief, which was worse than anything else done to them. The toilet surrogate was particularly appalling, unpleasant, and demeaning for Latvians, as Mr. Bisters summarized his experience. Worse, while transported on a barge, the same bucket applied for emptying the contents of the makeshift toilet was used for collecting rather potable water from the Volga River ${ }^{17}$. What can further reinforce the traumatic narrative is the recreated wooden barrack with plank beds differing little from the floor except that half of such beds are slightly above it. The ultra-ascetic design features nothing else but an electric bulb and a small stove in the form of a barrel ${ }^{18}$. The topic of the deportations and the fate of those subjected to the procedure constitute the chief focus of the museum exhibition that talks about the eviction of 15,000 Latvians to Siberia in 1941 and another wave that started in 1949 during the second Soviet occupation spell. Besides deportations and gulags, the museum covers forced collectivization and general cultural and economic Sovietization. There is still much room left for the Nazi occupation period spanning 4 years between 1941 and 1944, including its most atrocious aspect, such as Holocaust that led to $90 \%$ of the local Jewish population being effaced in 3 days' time ${ }^{19}$. The traumatic narrative, beyond doubt, cannot but influence if not shape Latvians' attitude towards the nations involved in the occupation atrocities in the capacity of aggressors.

\subsection{The Potential Effect of the Museum on Latvians' Attitude towards Germans/Russians}

Peace in Latvia and Europe overall per se should be a litmus paper of the utility and impact of war-presenting museums, such as that based in Latvia, yet peace is a cumulative product of multiple factors, including the presence of economic and military blocs, economic pragmatism reflecting an understanding that war is synonymous with multi-digital losses, and multi-polarity or the lack of a single dominant power, which makes for a more stabilized geopolitical environment, and the presence of nuclear weapons whose destructive potential ensures the containment of geopolitical ambitions. People's stance on the museum may reflect its perceived importance, yet no such surveys seem to have been conducted ${ }^{17}$ Sacks, J. (2020). The Best Museums in Riga, Latvia. Everybody Hates a Tourist. 2020. Available online: https://everybodyhatesatourist.net/riga-latvia-museums-a-tough-20th-century/ https://everybodyhatesatourist.net/riga-latvia-museums-a-tough-20th-century/. (Accessed on 17 April 2020)

18“The Museum of the Occupation of Latvia 1940-1991.” The Baltic Initiative and Network. n.d. Available online:

http://coldwarsites.net/country/latvia/museum-of-the-occupation-of-latvia-1940-1991/. (Accessed on 17 April 2020)

19“Museum of Occupation of Latvia, Riga.” Dark Tourism. n.d. Available online: http://www.dark-tourism.com/index.php/republic-of-ireland/15-countries/individual-chapters/935 -riga-occupation-museum\#p. (Accessed on 17 April 2020) 
to date, which indicates the need for a sociological effort on the part of research institutions that would identify and digitalize/quantify the positive influence of the museum in terms of attitude formation and peace maintenance ${ }^{20}$.

The presence of the Russian propaganda maintaining a solid foreign media presence ensures a portion of the foreign population is open to the idea of returning the political format from the $20^{\text {th }}$ century, which may hold good more for the elderly. Nostalgic, older people who could be living in the past toying with a false idea that brings back the Union will return their youth. Some may be left cold, without any grudge being harbored. Still, many people may come to develop a hostile attitude towards Germans and Russians for their perceived role in the annihilation and mistreatment of Latvians, which may affect the quality of interstate relations in economic, cultural, and other fields. This sentiment may be uneven intensity-wise, with some Latvians refusing to travel to these countries or buying goods sourced from these markets and others seeking to avenge of the historical grievance on Germans/Russians

(https://eng.lsm.lv/article/society/society/survey-latvians-slightly-less-apprehens ive-about-russia-than-they-were.a312870/). On the one hand, the formation of hostile attitudes does reduce Latvians' susceptibility to the propagandistic message that can put their resolve to retain statehood to the rough test, the Kremlin clique will go one day, as will the relevance to entertain a negative or, rather, skeptical attitude towards the country ${ }^{21}$. Yet it may persist, which is, perhaps, the major fallout of museums presenting a trauma, since such undisguised presentation can foster strong emotions translating into specific attitudes towards the conflict side involved in historical wrongdoings. The trauma museum dedicated to the Nazi/Soviet occupation may not prove as efficient as expected in the way of building a vigilant nation on the lookout for the reoccurrence of historical precedent $^{22}$. Much as the museum has stood for decades, the attitude has changed regardless, which may indicate the influence of other attitude-shaping factors that, however, could be adjusting Latvians' attitude now the museum's admission capacity is found reduced, while expansion plans are still to come to fruition. When they do, the attitude may assume a different trajectory when the trauma-presenting facility puts a greater number of sobering exhibits on public display.

\footnotetext{
${ }^{20}$ Survey: Latvians slightly Less Apprehensive about Russia than They Were. LSM.LV, March 15, 2019. Available online: https://eng.lsm.lv/article/society/society/survey-latvians-slightly-less-apprehensive-about-russia-tha n-they-were.a312870/. (Accessed on 17 April 2020)

21 "Last Week"s Neo-Nazi March Brings Shame to Latvia". (2018). The Digital Ambassador Club. Available online: https://www.wjcambclub.org/news/antisemitism/antisemitism-neonazi-latvia-shame. (Accessed on 17 April 2020)

${ }^{22}$ 'Survey: Latvians slightly Less Apprehensive about Russia than They Were. LSM.LV, March 15, 2019. Available online: https://eng.lsm.lv/article/society/society/survey-latvians-slightly-less-apprehensive-about-russia-tha n-they-were.a312870/. (Accessed on 17 April 2020)
} 


\subsection{Presenting Trauma at National Museum of Qatar: Safeguarding the Nation through Remembrance}

For decades, museums in Qatar focused their presentations in presenting and displaying, heritage, ethnography, archeology folklore and history. Never, thought of involving political narratives, especially traumatic one. However, the newly established National Museum of Qatar inaugurated with new philosophy that well expressed in the following statement: It gives voice to the unique story of Qatar and its people from earliest times to the present day and onwards towards its future. Designed to be both immersive and experiential, visitors can expect to encounter a rich environment to explore ${ }^{23}$.

The above statement reflects the intention of the museum to not only display objects and artifacts, but also to build a specific narrative about the nation. A narrative would cover the whole factors and history that helped forming the state. That is clear in the museum's presentation of the state history from 1500s to the present day. Such period narrates the history of the nation, formation of Qatar, its leaders, different events and the future vision of the state ${ }^{24}$. Vivid memories unfolded through testimonies of letters, maps, artefacts, currency, newspapers, historical photographs and stamps. Those testimonies displayed as witnesses to the crucial period the state went through during its development. Such display intended also to deepen the collective memory of the Qatari people (Introductory Panel of "The Modern State of Qatar" gallery, National Museum of Qatar, Doha, taken by the author on 3 February 2020).

Rather than talk about the state formation exclusively, the memories talk about distress, struggle, selflessness, and durability. These could be the morals and principles that the Qatari leaders wants absorbed by the nation. Apparently, Qatar now more than ever needs people resistant to malevolent external influences.

Qatar needs the trauma-presenting museum more than ever from lessons from the past aggression. While Qataries may be given to understand that conflicts with neighbors is an absolute malevolent via museum-based explanations, a political regime hundreds of miles away seems still to be nurturing a different idea all the while eying to capture the state in order to control its oil and gas wealth. As follows from the origin of the historical tangible items, which the museum laid available, people have shared their recent stories, which they did in an effort to retain the memory of the conflict period. Consequently, museum curators have gathered an aggregate of historical and contemporary testimonies, which is regarded as the first collections in Arabian Gulf Countries that dedicated to the showcase the historical and contemporary conflict topics. The contributed objects and testimonies were claimed to enhance the historical circumstances that Qatar faced during its different times. Rather than talk about recent

${ }^{23}$ National museum of Qatar, Available online:

https://www.qm.org.qa/en/project/national-museum-qatar. (Accessed on 25 May 2020)

${ }^{24}$ National Museum of Qatar, Available online:

https://en.wikiarquitectura.com/building/national-museum-qatar/. (Accessed on 17 March 2021) 
political conflict exclusively, the memories talk about ancestors' confrontation, battles, and endurance. These facts are the values that the politicians wants absorbed by the local and international audiences. If they become a measure of the selfness and national identity, they may drive a long way in the direction of firming people's unity and make populaces resistant to foreign pressure, which can be originated from a revanchist neighbor states. Within the recent conflict, Qatar now requires people's resistant to malevolent external influences. It also needs the society to recall the outrages more than ever now. Such hazardous geopolitical, oil-wealth and national progresses conflict are preparing that can put the state on the collision passage with those who used to harm and abuse the Qataries in the previous decades ${ }^{25}$.

As Qatar recently experienced uneasy political situation with its partners in the Gulf Cooperation Council (GCC) Bahrain, Abu Dhabi, Saudi Arabia and none GCC member Egypt, its attitude towards narrating the nation's history has changed. Thus, in the newly established National Museum of Qatar, the political history of the state with its neighbors is well-documented at the permanent exhibitions "The Modern History of Qatar" and "The Ramadan blockade". The exhibitions show how Qataries become less apprehensive about narrating a real political history that linked them over years with their neighbors. Going back to our main question, why Qatar needs the trauma-presenting exhibitions more than ever now? Apparently the trauma exhibitions dedicated to the history of political conflict are aimed to build awareness between the nation about the political history of the state. A history the state tried to keep hidden for decades as a respect to its neighbors. Hiding such facts and history did not prove as efficient as expected in the way of building an observant nation on the lookout for the reoccurrence of historical circumstances. Considerable as museums in Qatar have excited for decades, their approaches have changed, which may specify the impact of the factors of the recent political conflict that, adjusting Qataries' attitude towards showcasing their history. When the trauma-presenting exhibitions situate a greater number of factors on public domain, and hidden historical facts uncovered, audiences' attitude may assume a different trajectory towards the nations of the neighbors. The main purpose of establishing traumatic-exhibitions is to foster strong awareness, behavior and understanding that would translate into nation's specific attitude toward the recent political conflict the state has been through currently. It also aims to link historical facts with contemporary circumstances, which would logically analyze reasons and facts behind unfair and unjustified fabricated political disagreement and the blockade. That will help in well observe the tragedies of political history and the truth about the diplomacy of the state over decades. From within the traumatic-exhibitions the museum cultivate pride in Qataries ancestors and what they endured, which should enhance people's loyalty and sentiment towards their land and trigger their welling

${ }^{25}$ National Museum of Qatar: Heartbeat of Our Heritage, Available online: https://www.qm.org.qa/en/project/national-museum-qatar. (Accessed on 17 March 2021) 
to defeat any contemporary threats.

\subsection{How the National Museum of Qatar Builds the Traumatic Narrative: A Contact Zone}

$\mathrm{NMoQ}$ today has seen an escalation of its use to recent instrumentality to influence local and international communities and stakeholders. The rationale of public authority, enablement through recognition, unrestricted collaboration, and political agency have changed the practice of museums in Qatar (Witcomb \& Message, 2015). Apparently, this is in respond to the recent political conflict, which influenced Museums Authority to form and display difficult political circumstances that have both challenged the government and society alike. This is a direct engagement between the national museum and the community in Qatar. The discussion in this section provides a description of the museum use of historical and contemporary incidents, to explain how and why the recent conflict happened and its consequences over the community. Such an iconic and evocative presentation has; without doubt, present a clear picture for the national and international audiences of the injustice attack that Qatar has been through. As stated earlier the museum builds its traumatic narrative through two main galleries, "The Modern History of Qatar" and "The Ramadan blockade", those two galleries split into two different historical eras.

First gallery "The Modern History of Qatar" is well addressed the historical conflicts by displaying various manuscripts, illustrations and maps that describe battels, disputes and betrayals that Qatar experienced with its neighbors during the nineteenth century (Figure 5).

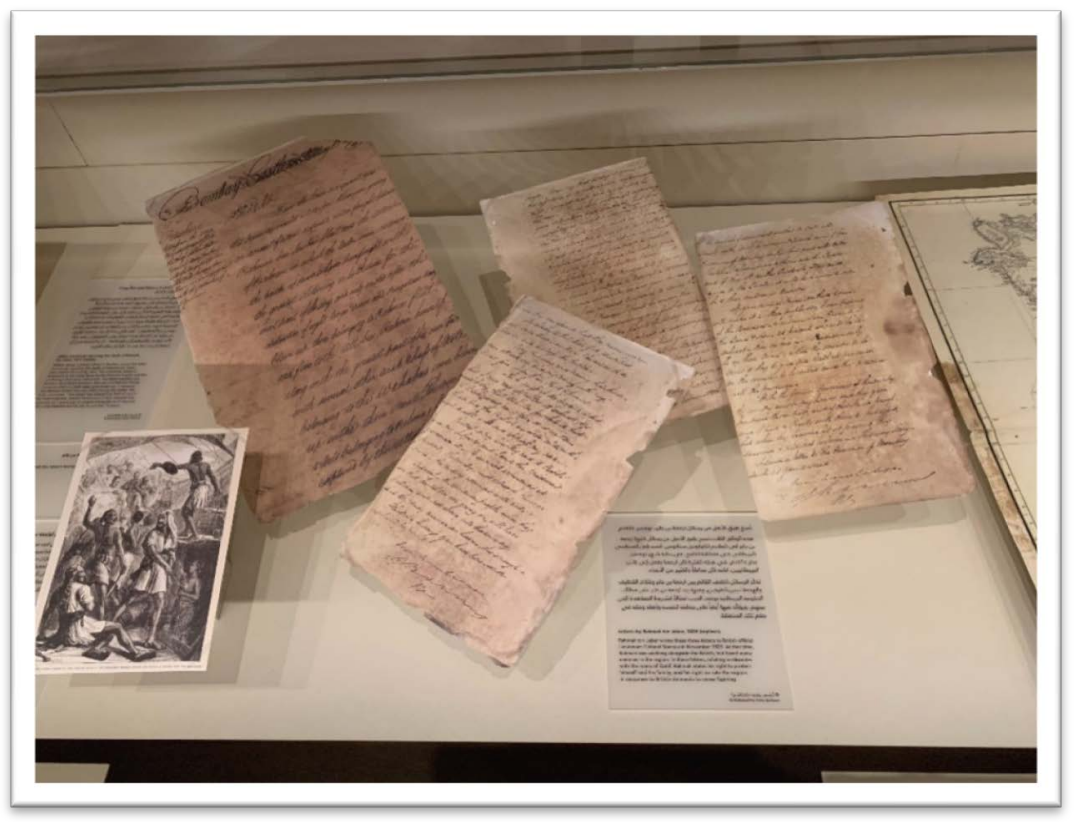

Figure 5. A public display of manuscripts, letters and maps for the first time indicates the nature of the historical relationships between Qatar and its neighbors, taken by the author on 2 February 2019. 
The museum ensures the availability of the contents to the local and international audiences by placing texts in Arabic and English at their disposal, yet this somewhat curtails the depth of explanation attached to the exhibits. Tensions between Qatar and rulers of Abu Dhabi, Bahrain and Saudis displayed one by one through details of continuance battels and tensions. Such as, the battle of Al-Wakrah in 1867, Sheikh Jassim bin Mohammed bin Thani capture in 1867, the second destruction of Doha in 1867, the battle of Damsah in 1867, the battle of Jabel wakrah in 1868, the battle of Mesaimeer in 1851, Al Udayd dispute 1878, the development of dispute between Qatar and Abu Dhabi between 1886-1880 and Abu Dhabi attack over Qatar. To draw audiences' attention to the significance of these events, tiny details in those battles were narrated. For instances, how the Qatari stood alone to defend their land without any external help from the Ottoman, or the British who actually helped the ruler of Abu Dhabi Sheikh Zayed; killing of Sheik Joaan the son of the Qatari ruler along with other Qataris while defending their land in 1888; and the imprisonment of Sheikh Jassim after being betrayed by Bahrain's ruler. Throughout this narrative, there is a repetition of the unification idea of the Qatari tribes under one leadership in their defense. Despite such a traumatic presentation, the exhibition emphasizes the important role of tribal unification in the formation of the state. Unification that is, still importantly needed during the state current political dispute with the neighbors.

The second traumatic gallery "The Ramadan Blockade" was launched on November 2019, which dedicated to highlight the blockade that imposed over Qatar on May 2017 by its neighboring countries. The display focused in highlighting every aspect of the blockade, right from its beginning to its effects in the Qatari sociopolitical life. The foreign conflicts that Qatar faces with its neighbors have become central to showcase the social and economic values of cultural display. Within this exhibition, justice, and the statement of political as well as human rights, are ideologies have become essential to the dialogue at the national museum. The interpretation of the contemporary incident comes together to show that museum practice in Qatar has intersected and associated its policy with political and social events. Analyzing such section also shows how far museums can make contribution to understanding about political movements and their social impacts (Al-Hammadi, Exell, \& El-Menshawy, 2020). The exhibition "the Ramadan Blockade" starts with a brief biography of the Emir of Qatar Sheikh Tamim bin Hamad. Following to that the introductory panel of the exhibition presented with:

"On 5 June 2017, the kingdom of Saudi Arabia, the United Arab Emirates, Bahrain and Egypt abruptly severed diplomatic ties with Qatar: All cross-border routes were closed, Qatar was isolated and many restrictions were imposed. The blockading countries announced conditions to lift the siege; Qatar rejected these as a violation of its autonomy and sovereignty. The blockade caused many injustices, including the separation of families and difficulties for students, pilgrims and the sick. Qatar responded with legal proceedings through the International 
Court of Justice. HH Sheikh Tamim faced this challenging period with wisdom and forbearance. Qatar has overcome the crisis thanks to its local resources and the determination of its citizens and residents, allowing the nation to move forward on a path of development and prosperity" (NMoQ labeling panel, 2019) ${ }^{26}$.

The introductory panel explains in details four main aspects, which framed the extent of the blockade and the blatant attack the state faced on the civil and governmental levels. The first is an emphasis in its timing, which was the holey month of Ramadan. The second are the unreasonable causes, which was the violation of the state sovereignty. The third are the social consequences of the blockade. The fourth are the locals' reactions, as well as the way that the Emir of Qatar dealt with such crucial incident through using legal and international channel, the International Court of Justice. Those four points aimed to influence and persuade the audiences with the museum's point of view around the political facts behind the blockade. Indeed as we analyze the exhibition panels and captions, we recognize that contemporary museums sit at the intersection of a nation's political activities (Al-Hammadi, Exell, \& El-Menshawy, 2020). The display of such political materials, such as the historical battles and the blockade, help the museum in its approach toward being a contact zone. The museum is theorizing battles and blockade and using advocacy function following a construction of issue-based presentation. Furthermore, the museum displayed several applications (Figure 6 and Figure 7) of National Human Rights Committee (NHRC) in Qatar for people who submitted their complaints and the social consequences they have been through.

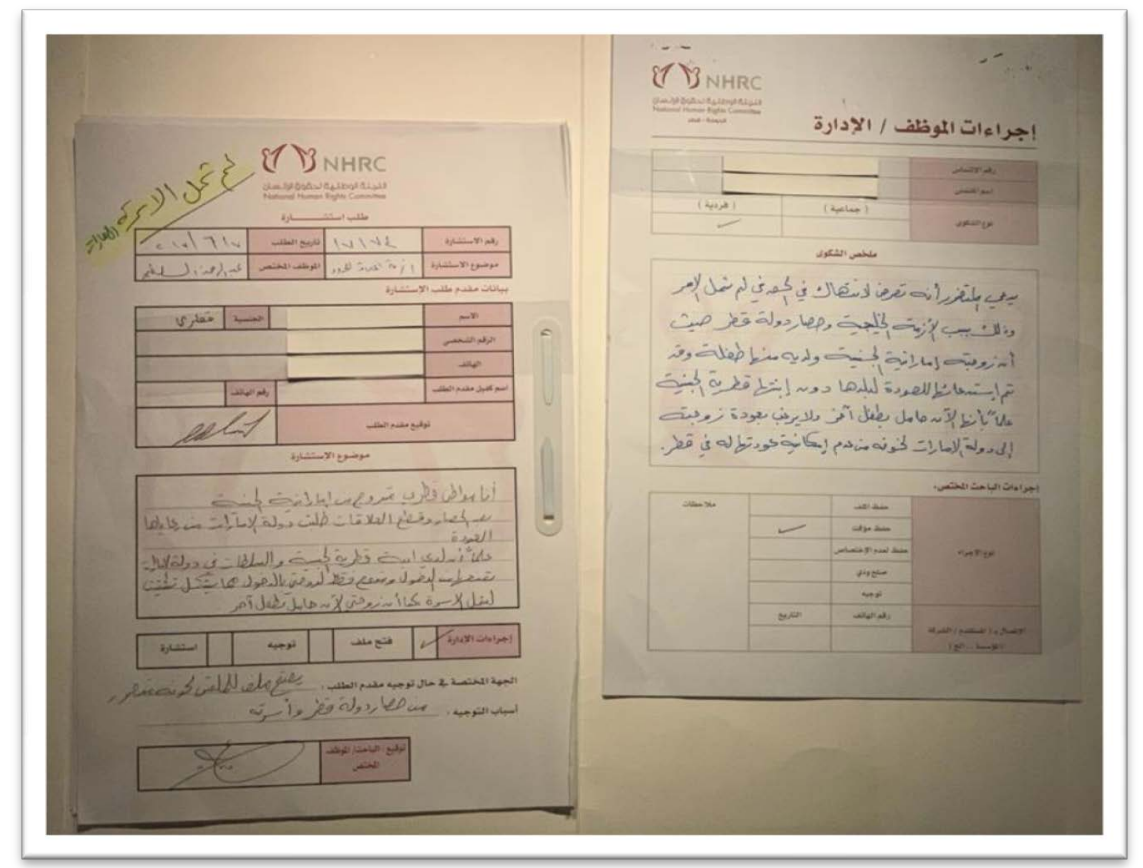

Figure 6. A complain of a Qatari who married to Emirati woman, complaining that the authority of UAE called for his wife to return back to UAE without her Qatar child.

${ }^{26} \mathrm{NMoQ}$ labeling panel, taken by the author on 19 November 2019, Doha, Qatar. 


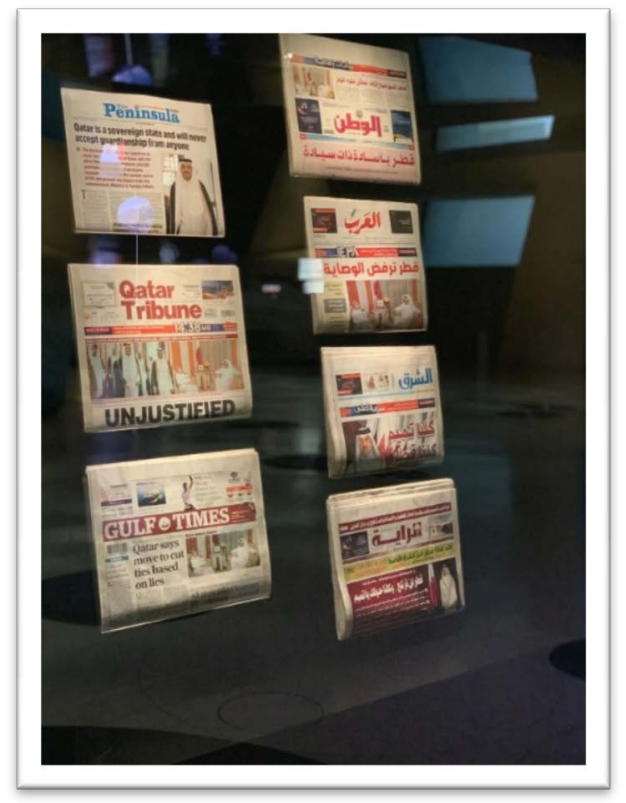

Figure 7. The intensive engagement of the media with the incident (Taken by the author).

From within this exhibition, as a public institution, the museum plays a role in representing the community's concerns. The exhibition encompasses interaction between the local communities and governmental bodies, which regulate a guided museum presentation. The collective political incidents challenged and influenced cultural institutions in Qatar, and their practices transformed. The museum became inclusive in its collecting process and more receptive to contemporary issues. The exhibition clearly articulated the communities' reaction towards such political incident, as well as it represents the engagement of the media. The museum acted here as an official platform that documents permanently the impact of the blockade (Al-Hammadi, Exell, \& El-Menshawy, 2020). The political circumstances have provided the new museum opportunity to engage with the community and develop a new political culture approach. The incident imposed the urgency of change within presentation and collection policies. Thus, the museum moved from its social responsibilities to reflect its prevailing conviction of the importance of its interaction and response to crises (Gollin, 1965).

The value in the museum's engagement policy, lays in the documentation of the political conflicts, in comparison to the previous museum's presentation, where a political presentation was totally nonexistent. The museum approach that is explored within the traumatic exhibitions might provide a possible hint to the upcoming change in the political practice of the Qatari politicians with the sieged countries. The museum believes that the exhibitions will offer an excellent opportunity to ordinarily people to learn much about the case of the recent blockade and political inter-relationships with the neighboring countries. As they undergo a history-making presentation of political conflicts, a comprehensive understanding based in collected evidences would provide knowledge on the causes and effects of the blockade that is insufficiently unclarified by the sieged 
countries. Meanwhile, the blockade exhibition gives a meaningful and permanent understanding of the effect of such political action, which may never result from conservative media coverage. In its role, the museum became predominantly concerned with kind and sources of information that are distinctive to the political event. For instance, the actual social effects over families that included separation of husbands and wives, or parents and children and cut of social tie fabric between GCC families. It was understood, that more observation about social effects and movement associated with the blockade, requires the development of presentation that addresses and understands the interrelationships between politics and culture, political culture and cultural politics, especially if the data at hand analyzing examples of direct effects over the community (Maho, $1968)^{27}$. Usually museums presentation tends to be traditional, and due to the predominance of constructivist approaches within such traditional presentations those exhibitions lacked disciplinary dialogue.

Unlike the traditional museum presentations, which are usually rich nostalgic sites by their presentation of physical archaeological, ethnographical and historical objects? The launch of the Blockade exhibition exists more as an experience rather than a traditional exhibition. By taking steps of socio-politically approach to present the hardship time for the communities and politicians alike, the exhibition creates a space of a contact zone between the communities and the government. The exhibition as a contact zone offers audiences an open participation in the argument in the contemporary political crisis. It facilitates direct interaction between the audiences, politicians and the political crisis with its socio-political consequences. Interestingly, within such presentation, an important element has contributed to the effect of the presentation, which is the reliance on the tension that the displayed materials create. This is true especially if we consider the fact that political "challengers" as matter lack routine entree to decision-makers strategy (Tilly, 1978). This is a presentation of an angry and loudly voice into normally a quiet zone, which is a museum. To implement that change in museum practice, presentation of political crisis requires an interdisciplinary team and background as well as a combination of techniques (Witcomb \& Message, 2015).

To conclude the discussion in this section, we shall say that the way of creating a contact zone in the museum is by consultation, collaboration and employing direct engagement strategies.

\section{Conclusion}

We must recognize that while museums presenting trauma may seek to educate and evoke pride in visitors for fellow residents, the main task may be to avert the recurrence of what led to the trauma, which could be blockade, war or occupation that cut aggressors loose. This is achieved via reminding people of historical

${ }^{27}$ Mahon, G. H. (1968). Memo to S. D. Ripley, 'Federal Government finance of the Poor People's Campaign," May 21. Smithsonian Institution Archives, RU 145, Smithsonian Institution, Assistant Secretary for Public Service, Subject Files, 1961-1974. 
calamities, as well as documenting current political difficulties. This is essential given the possibility of collective or individual historical amnesia as many people tend to forget, especially if not the direct witnesses and participants of the events. Museums, such as that in Latvia that are dedicated to the Nazi/Soviet occupation reflect an understanding on the part of the government that people need reminding of what happened. In part because, when properly represented and linked to aggressors, atrocities from the past can foster a national identity resistant to revanchist foreign powers, such as Russia and prevent the large-scale rise of neo-Nazism that can have a range of adverse political, economic, and other outcomes.

Likewise, for the first time in its history, museums sector in Qatar is following this new approach and functioning as contact zone through educating people to prevent the repetition of what led to the trauma. Previously, such political unease was never displayed or talked about in public arenas in Qatar. Hiding historical facts in previous museums is viewed as inability to provide theoretical contexts and analysis related to hardship circumstances and the causes they represent. In contrast, currently museums in Qatar are using new methodology of displaying vital moments in its history. The current political incident came to proof the necessity to remind people about historical events and their link to the recent incidents. The museums as a contact zone provide public lessons from the past that indicate we shall forgive but we should not forget.

\section{Conflicts of Interest}

The authors declare no conflicts of interest regarding the publication of this paper.

\section{References}

Al-Hammadi, M., Exell, K., \& El-Menshawy, S. (2020). Camel, Blockade and a Historical Memory Perspective: A Theme of Historical Memory Portrayed at Qatar National Museum. Studia Antiqua et Archaeologica, 26, 185-198.

Apor, P. (2014). An Epistemology of the Spectacle? Arcane Knowledge, Memory and Evidence in the Budapest House of Terror. Rethinking History, 18, 328-344.

https://doi.org/10.1080/13642529.2014.890371

Archer, P. (2010). The Quotable Intellectual: 1,417 Bon Mots, Ripostes, and Witticisms for Aspiring Academics, Armchair Philosophers... and Anyone Else Who Wants to Sound Really Smart. Simon and Shuster.

Bartol, C. R., \& Bartol, A. M. (2014). Introduction to Forensic Psychology: Research and Application. Sage.

Bassanelli, M., \& Postiglione, G. (2003). Museography for Traumatic Memories: Re-Enacting -The Past. Interventions/Adaptive Reuse: Int/AR, 4, 6-13.

Bishop Kendzia, V. (2010). Clichés Reinforced, Clichés Challenged. In Cultural Representation of Jewishness at the Turn of the 21st Century (pp. 43-57). EUI Working Papers HEC 2010/01, Department of History and Civilization.

Bishop Kendzia, V. (2014). Jewish' Ethnic Options in Germany between Attribution and Choice: Auto-Ethnographical Reflections at the Jewish Museum Berlin. Anthropologi- 
cal Journal of European Cultures, 23, 60-70. https://doi.org/10.3167/ajec.2014.230205

Black, G. (2011). Museums, Memory and History. Cultural and Social History, 8, 415-427. https://doi.org/10.2752/147800411X13026260433275

Brown, T. P. (2004). Trauma, Museums and the Future of Pedagogy. Third Text, 18, 247-259.

Davoliute, V., \& Balkelis, T. (2012). Maps of Memory: Trauma, Identity and Exile in Deportation Memoirs from the Baltic States. Part of the Lithuanian Literature and Folklore Institute Project Entitled "Maps of Memory: Transcription and Transference of the Experience of Displacement in the Memoirs of Deportation", and the Lithuanian Research Council's "National Development Programme for Lithuanian Studies 20092015", Vilnius.

Gollin, A. E. (1965). Sociological Research in Response to Crisis: The Case of the March on Washington for Jobs and Freedom. In The Annual Meeting of the Eastern Sociological Society. Bureau of Social Science Research.

Greenberg, R. (2007). Museal Representations of Genocide. Healing or Reactivated Trauma? Gradhiva, 5, 1-7.

Gundega, M., \& Koknevièa, T. (2008). The Museum of the Occupation of Latvia. The Public Historian, 30, 163-165.

Kulasekara, D. (2016). Representation of Trauma in Contemporary Arts. Journal of Humanities and Arts, 4, 35-60. https://doi.org/10.30958/ajha.4.1.3

Luke, T. W. (2002). Museum Politics: Power Plays at the Exhibition. University of Minnesota Press.

Nye, J. (2004). Soft Power the Means to Success in World Politics. Public Affairs.

Pollock, P. (2013). After Affect-After Image: Trauma and Aesthetic Transformation in the Virtual Museum (p. 2). Manchester University.

Salazar, A. (2015). Trauma, Memory, and Representation: The Role of Collaboration in the Development of the Museum Exhibit "Remembering the Killing Fields", Collaborative Anthropologies (pp. 83-106). University of Nebraska Press.

Sherman, A. L. (2016). Sharing God's Heart for the Poor: A Personal or Small Group Bible Study. World Vision Canada.

Silk, A.-de S. (2016). Mediating Memory in the Museum: Empathy, Trauma, Nostalgia. Palgrave Macmillan.

Silverman, R. (2015). Museum as Process. Translating Local and Global Knowledges. Routledge.

Tilly, C. (1978). From Mobilization to Revolution. Addison-Wesley.

Witcomb, A., \& Message, K. (2015). Contentious Politics and Museums as Contact Zone. In A. Witcomb, \& K. Message (Eds.), The International Handbooks of Museum Studies (pp. 253-282). John Wiley \& Sons, Ltd.

Wolfgang, M. (2013). Does War Belong in Museums? The Representation of Violence in Exhibitions. Majuskel Medienproduktion $\mathrm{GmbH}$. 